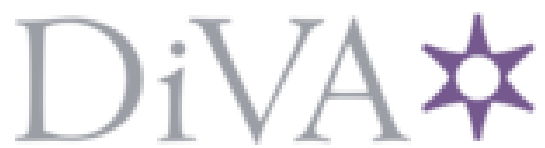

http://www.diva-portal.org

\title{
Postprint
}

This is the accepted version of a paper published in Research in Comparative and International Education. This paper has been peer-reviewed but does not include the final publisher proof-corrections or journal pagination.

Citation for the original published paper (version of record):

Alexiadou, N., Dovemark, M., Erixon-Arreman, I., Holm, A-S., Lundahl, L. et al. (2016) Managing inclusion in competitive school systems: The cases of Sweden and England Research in Comparative and International Education, 11(1): 13-33 https://doi.org/10.1177/1745499916631065

Access to the published version may require subscription.

N.B. When citing this work, cite the original published paper.

Permanent link to this version:

http://urn.kb.se/resolve?urn=urn:nbn:se:umu:diva-116811 


\title{
Managing inclusion in competitive school systems: The cases of Sweden and England
}

\author{
Nafsika Alexiadou ${ }^{1}$ \\ Department of Applied Educational Science, Umeå University, Sweden \\ Marianne Dovemark \\ Department of Education and Special Education, University of Gothenburg, Sweden \\ Inger Erixon-Arreman \\ Department of Applied Educational Science, Umeå University, Sweden \\ Ann-Sofie Holm \\ Department of Education and Special Education, University of Gothenburg, Sweden
}

\section{Lisbeth Lundahl}

Department of Applied Educational Science, Umeå University, Sweden

\section{Ulf Lundström}

Department of Applied Educational Science, Umeå University, Sweden

\section{Research in Comparative \& International Education, March 2016}

\begin{abstract}
The last 40 years have seen great political attention to issues of inclusion in education both from international organisations but also individual nations. This flexible concept has been adopted enthusiastically in education reforms concerned with increased standardization of teaching and learning, decentralization of education management, reduced teacher autonomy, and marketization of school systems. This paper draws from a research project that explores inclusion as part of the education transformations in England and Sweden. These two countries have been very different in their state governance and welfare regimes, but have been following similar directions of reform in their education systems. The paper evaluates the changing policy assumptions and values in relation to inclusion in the schooling changes of the last few decades, through an analysis of policy contexts and processes, and a presentation of selected empirical material from research in the two countries. We argue that, despite the similar dominant discourses of competition and marketization, the two education systems draw on significantly different paradigms of operationalizing inclusion, with distinct outcomes regarding equality.
\end{abstract}

Keywords: Education policy, marketisation, inclusion, England, Sweden.

\footnotetext{
${ }^{1}$ Corresponding author:

Nafsika Alexiadou, Department of Applied Educational Science, Umeå University, Sweden.

Email: nafsika.alexiadou@umu.se
} 


\section{Introduction}

The landscape of education policy and practice is changing fast across Europe. Schools are redesigned along remarkably similar lines by governments that follow international reform trends and adopt similar processes of transformation. On one hand we observe a continuous expansion of education, certification, and access to early-years and higher education, and renewed discourses of inclusion for the increasingly diverse student populations (OECD, 2012). On the other, these positive trends are taking place in a context of economic, social and political restructuring that is captured by the term of 'neoliberalism'. The 'creative destruction' that Harvey (2005:2) associated with the turn to neoliberalism meant a dismantling of earlier forms of economic and political organization that were developed in Europe in the form of welfare systems, to protect the population from the destabilizing effects of unfettered market forces. Drawing on Dale \& Robertson (2009) our point of departure is that neoliberal discourses have contributed to new modes of regulation of education policy, with real effects on policy and practice within national systems of education. The reshaping of welfare and schooling institutions through market relationships has been changing what Rawolle (2013) calls the social contracts that underpin "the balance between values or priorities, such as that between equity and markets" (p.232).

The two countries of our article, England ${ }^{\mathrm{i}}$ and Sweden, have experienced very similar trajectories in their welfare system reforms of the last 35 years, and have keenly adopted selective neoliberal ideas and mechanisms in order to transform and 'modernize' their education systems. The boundaries between traditional public and private logics have been eroded in both countries, through the introduction in schools of market mechanisms but also through the extensive involvement of private actors in the provision of core and peripheral education activities (Beach \& Dovemark, 2011; Junemann \& Ball, 2013; West, 2014).

Education is also a highly political institution that is historically and socially constituted, with a partly autonomous existence, although framed by regulations, structures and institutional histories. The Swedish school was shaped by a long period of social democracy, and responds in different ways to marketization reforms as compared to the English school that had been subjected to neoliberal policy assumptions for a larger part of the post-war period. Consequently, conceptions of equality of opportunity, and a 'school for all', have been challenged and re-defined in the two systems, and the outcome of this process is a picture of diversity in the ways in which teachers, head-teachers and pupils understand, practice, and experience inclusion.

This article draws on a research project ${ }^{\mathrm{ii}}$ that explores schooling reforms based on marketization and competition, and their effects on inclusion in secondary education ${ }^{\mathrm{iii}}$ in Sweden and England. We wish to problematize the relationships that emerge from the establishment of schooling systems based on the principles of the market, and to argue that policy making in education in both Sweden and England is implicated in the creation of the problems we observe, but also has the potential for providing solutions. A note on our understanding of 'policy' is needed here. By policy we mean the interaction between the designs for schooling that come from 'the top' through government and international agendas, but also how these agendas are mediated and enacted in schools, by pupils, teachers, headteachers, and parents. We view policy as both institutionally and socially constructed and 
enacted by actors who are located within specific frameworks and hence, regulations, histories and cultures of practice. Drawing on literature that applies critical lenses to policy and comparative studies (Ball, et.al, 2012; Gulson, et.al, 2015; Phillips \& Ochs, 2004) our methodology entails (a) an analysis of the context and processes of policy development, reviewed in relation to institutional structures and state regulation; and, (b) a focus on policy mediation and enactment by the actors who experience the force of the reforms, and the ways in which policy objectives are (often) re-made especially when these are stated in the form of 'outcomes' to be achieved. As such, our perspective views policy as a deeply political exercise at all instances of its evolution and enactment. But, our paper also has a comparative ambition. We explore how each country interacts with the ideas and mechanisms of neoliberalism, and in particular marketization and the ensuing school competition, and the effects of this interaction on conceptions and experiences of inclusion.

\section{The Study}

Our research draws on a large body of qualitative and quantitative empirical material in both countries, collected over a period of three years (2012-15). It entails a combination of policy and institutional analysis, and fieldwork that involves: (a) a large survey at the municipality ${ }^{\text {iv }}$ level in Sweden, b) a total of about 160 interviews with teachers, head-teachers, local government actors (in 2 regions in Sweden, and in two local authorities in the Midlands in England) ${ }^{\mathrm{v}}$, and about 60 interviews with school students in both countries, (c) a documentary and statistics collection at school, local, and national levels, and (d) observations of school 'life' in order to capture the multiple facets of change that schools are going through. For this paper we focused on the ways in which our research participants understand and conceptualise the relationships between marketization and inclusion, their experiences of competition and school choice, and the effects of these processes on their work and identity. Drawing on Alexiadou (2001), the material was analysed using a combination of thematic coding and discourse analysis, and this was adjusted to the particular type of data. The analysis involved an initial inductive approach where transcripts, observation notes, and documents were de-constructed and themes were formulated that captured the meaning of the text. The themes were clearly defined, and of a similar level of abstraction, and represented a first level of analysis, which meet the criteria for logical consistency, and representativeness. Themes were then described for their particular characteristics and links are drawn between them (ibid). They refer to descriptions of (i) school and local contexts, including local histories, descriptions of the school market, and external pressures related to competition, inspection, and league tables of performance; (ii) the process of marketisation in relation to parental and student choices, and the institutional responses to these, including internal school responses in relation to meeting the requirements for performance, and how these affect the curriculum, pedagogy and classification of students; (iii) finally, we focused on the outcomes of these processes in relation to the question of inclusion and equality, through analyzing individual and institutional responses around different categories of students.

The article is organized in two parts. First, we present our comparative analysis of the history, context and process of education policies in Sweden and England, with a particular focus on reforms that shape equality discourses. In the second part, we illustrate some of the outcomes of these reforms, by drawing selectively on our empirical research. 


\section{Part I}

\section{The early context of change and the logics of inclusion}

During the post-war period in Europe, the state was seen as a legitimate interventionist authority that, through social and redistributive policies kept economic growth in balance with concerns around social equality - or at least, the faith in meritocratic systems of opportunity, where effort (in education, and work) were rewarded with social and economic advancement (Crouch, 1999). This was broadly reflected in the ways the school systems of Sweden and England were organized, but with some fundamental differences in the two countries.

Sweden had followed a much more active redistributive politics in welfare as well as education (Sejersted, 2011) compared to England, as well as a fully comprehensive education. Governed by a Social Democratic Labour party (exclusively or in coalition in the period 1932-1976), the country constructed a universal and generous welfare state that reflected an ideology of justice, was based on strong political consensus and supported by high taxation (Esping-Andersen, 1993). In education, this period was characterized by expansion of primary and secondary education that were geared towards achieving equality and to a high degree uniformity. All children were supposed to go to schools of equal and high standards, and to have equal opportunities to attend tertiary education. The decision on the 9-year comprehensive school in 1962, and upper secondary school in 1970 saw academic and vocational programs under the same institutional structure. The compulsory school practiced little or no academic differentiation within the school, not even at lower secondary level, but deferred selection of students to later stages of education. The education system had a strong social justice orientation, and emphasized equal education standards regardless of children's socio-economic background or geographical location. Private schools were practically nonexisting (Lundahl, 2002; Telhaug et al., 2004). The system was strongly regulated by the state, as were also the national curriculum and the regulations concerning the teaching profession.

The situation in English education of the same period was very different, even though it was also an era of construction of a welfare state. But, it was a fairly liberal welfare state based on a 'modest universalist' model of assistance that allowed the market to 'reign for the grown social strata demanding superior welfare' (Esping-Andersen, 1993:26). The post-war education system was diverse, divided along lines that corresponded to social class and religion. The political agenda of the period was one of achieving 'meritocracy' - based on ability tests that replaced parental ability to pay as a criterion of receiving secondary education (David, 2003). The principle of 'equality of opportunity' was shared by both main political parties of the time, but it manifested itself in the development of a selective 'tripartite' system of secondary grammar schools (selecting pupils on the basis of ability at the age of 11), the secondary modern and the technical schools. The three types of schools had different curricula and certification possibilities, with only the grammar school allowing access to tertiary education. Comprehensive (non-selective) secondary schools were only introduced gradually in the late 1960s, a very slow process that did not happen uniformly across the country. By the early 1980s most (but not all) local authorities had completed their reorganization of secondary schooling along non-selective lines ${ }^{\mathrm{vi}}$. But the differentiation that used to characterize the tripartite schooling was reproduced internally in the new 
comprehensive schools. In their majority comprehensives were organizing ability-based classrooms which, even though following the same curriculum, were reflecting the old divisions of the selective school patterned on socio-economic and gender related performance (Benn \& Chitty, 1997). It should be noted here that in parallel to these developments in the state sector, England has a fee-paying private sector (schools usually known as 'independent' or 'public' schools), that since the Second World War have been educating about $7 \%$ of the pupil population ${ }^{\mathrm{vii}}$. As Walford (2009) suggests, the political and ideological importance of these schools is "far greater than this proportion would indicate" (p.727), given their connections to the prestigious Universities (for instance, $43 \%$ of Oxford University students came from the independent sector in 2013), and to positions of political and government power (Social Mobility and Child Poverty Commission, 2014). Even though these schools rely on their funding on private sources, they receive financial state support, through significant tax benefits as a result of their charitable status.

The two national contexts designed a very different system of education in that post-war period, and this is important when we think about inclusion and equality in education and what schools, teachers, parents, were expecting from the system. Even though there was a discourse of equality in education in both countries, the Swedish school was geared towards 'equal outcomes' for children, whereas in England the emphasis was on 'equality of opportunity' to compete for differential school pathways.

By the early 1970s and the fiscal crisis that defined the decade, this post-war consensus was seen in both countries as no longer fit for the modern economy. Alternatives were sought, and, advanced economies in Europe selected different paths to a resolution: For some years Scandinavian countries opted for strengthening the social democratic welfare traditions, whereas in the UK there was a period of tensions between a similar path of social democracy combined with a strong regulatory state, and, the ambitions of establishing a freer market economy (Esping-Andersen, 1993). Both paths needed a reform of state roles, and functions. Throughout the 1980s and 1990s, following reforms of radical decentralization in Sweden, and a combination of decentralizing provision with a strengthening of central regulation control in England, we observe a shift in the role of the state in both countries: From being the main provider of schooling, to being the guarantor of appropriate institutional frameworks for the operation of schools by multiple state and non-state providers, often in highly competitive, school quasi-markets (Jones, et al., 2008; Lundahl, 2014).

The features of these markets where "several producers compete over public tasks and/or when internal steering systems are developed with the market and industry as models" (Montin 2006:7) are by now familiar across Europe. They are characterized by policies of school choice, competition, commercialization and often privatization, driven by the belief that diversity of school providers (public and private) and their competition for resources will increase the effectiveness and responsiveness of the system. The political argument is that these mechanisms give incentives to schools and teachers to improve the quality of education they provide, and to parents and students the freedom to select the most appropriate education for them, but also the tools to hold schools accountable for issues of quality. These are arguments and agendas intending to reshape education systems, and conceptualisations of education purpose and education values. 
Inclusion and sometimes references to equality, equity, or 'equality of opportunity' (depending on the country), are central to these new politics of marketization, even though their relationship to economic agendas is often problematic (Jones et al. 2008). But, there are no fixed definitions of inclusion or equality over time and certainly not across national boundaries. The openness of the concepts of inclusion and equality suggest that they should be understood as contested concepts that take meaning from the particular historical and institutional contexts within which they appear (Lappalainen \& Lahelma, 2015). A similar observation applies to the politics of equality in education policy that are "under constant flux, constructed through processes of changing governance and accountability, but also deliberation" (Alexiadou, 2016:1). In the post-war period, the Swedish social democratic tradition emphasized the redistribution of opportunities through high quality comprehensive education, conforming to Silver's (1994) 'monopoly paradigm' of social inclusion where there is emphasis on citizenship and "extension of equal membership and full participation in the community" that creates "a bond of common interest between otherwise unequal insiders" (p.543). England on the other hand is a liberal welfare regime: diversification of schools and strong internal differentiation, fit a specialization paradigm of inclusion (ibid. p.542) where individuals enter networks of voluntary exchanges according to their degree of preparation from the school system (and in fairly close connection to their gender and socio-economic background). Inclusion in this context refers to the ability of individuals to exercise their right to participate, and corresponds to a minimum definition of equality of opportunity. What we observe in the post-1990s period is that Sweden is moving away from the monopoly paradigm to a quasi-market in schooling that resembles more the English specialization one. But, as our empirical data suggests, the similar direction of schooling reforms in the two countries have different consequences for the understandings and practices of inclusion.

\section{Market designs and school reforms - development and evolution}

The early steps in the introduction of marketization and part privatization in Sweden coincided with a deep economic recession in the early 1990s that resulted in the rolling back of state expenditure and functions. In education, this was reflected in the belief that the central state could no longer govern the sector, and was not responsive to the needs of parents and students. Significantly, a series of decentralization reforms that had begun earlier, intensified and local governance was seen as the answer to problems of management and quality of the system (Lundahl, 2002). In the period 1989-1993, important decisions were taken to divide further the responsibilities between state, municipalities and schools, giving local actors considerable freedom to allocate resources.

By early 1990s the Swedish system was highly decentralized and with opportunities for a publicly subsidized private system to develop (Blomqvist, 2004). The reforms included: a) introduction of management by objectives and results, b) decentralization (including several changes of which devolution of funding and employer responsibility to municipalities was crucial), c) the introduction of quasi-markets of schooling (the 'freedom of choice' reforms of 1992 and 1993) with parents allowed to select a school for their child, but also, through the introduction of a voucher system and the provision of state subsidies established independent (fristående) schools, commonly called free schools. The last few years have been 
characterized by re-centralization, a "centralized performance-based management" (SOU, 2014:5) including reforms such as, d) standards-based national curricula and new grading systems, e) a new Education Act (SFS, 2010) implying an expansion of state regulation (and applying to both public and independent secondary schools), f) increased pressure from the Schools Inspectorate, and g) strengthened demands for systematic quality work (Lundström, 2015) including the growth of evaluation systems for the production of information for school choice and evaluation of goal achievement.

Free-schools which are licensed by the national Schools Inspectorate can be set up by a broad variety of actors including non-profit and for-profit organisations (individuals, parents, community organisations, religious congregations, business companies). In the 2010s, nine out of ten free schools are run as corporations with a possibility to extract profits. In a legal sense, all free schools are private, they are open to all, free of charge and fully tax-funded through the education voucher, which is provided by the student's home-municipality. Publically-owned schools can be transformed into free-schools by acquisition of individuals or organizations (Swedish Competition Authority, 2009). Upper secondary students can in principle apply to any school in the country and if accepted, bring their funding via the educational vouchers. A yearly updated national "national price-list" recommends the appropriate voucher sum for study programs, which in practice however varies between municipalities (Govt. Bill 2008/09:171).

By 2000, Swedish schools had more autonomy in allocating teaching hours, choosing instructional contents and methods, and deciding on class sizes than in most other countries (OECD, 2002). However, it is notable that there were, at the same period, reforms that were driven by the desire to retain the inclusive character of schooling, and inclusive intentions are still prevalent. For instance, there was a common organization between early childhood and primary education, and at the upper secondary level stronger curricular links between the academic and vocational programs - both giving access to higher education. In the latest reform, Gy11, these links are weakened.

In England the 'big' reforms in education began a decade earlier. The 1980s saw a radical shift in thinking about the links between education and the economy, and the introduction of market driven reforms around the organization of schooling - primarily through increasing parental choice of school, and incentivizing competition between schools. In a system that was already fairly decentralized in the provision of education (including decisions about the curriculum, assessment, and school admissions depending on the religious status of the school), a much stronger centralization of control over education took place. In 1988 the Education Reform Act brought all the earlier reforms together, and introduced (a) a shift of financial responsibilities from the local government level to schools; (b) it allowed secondary schools to 'opt out' of the control of the local authority, and acquire a grant-maintained status which would entail funding directly from the government, and control over their admissions policies; (c) it (further) increased the power of parents to select a school for their child; (d) it introduced a national curriculum for all state schools at compulsory level, accompanied by attainment targets, and national tests, and finally, (e) it introduced new types of schools (the city technology colleges) intended to be partially funded by industry. These reforms combined 
unprecedented degrees of centralization in the form of establishing a national curriculum and assessment, with high decentralization of powers and funding to the levels of the school circumventing the (perceived) politically obstructive local education authorities (Brock et al., 2007). Schools were given strong incentives to compete over students since this was now directly tied to financial resources, but also to compete over 'good' students, since the national tests had to be published in league tables of comparative performance produced by the local authorities.

The arrival of a 'New Labour' government (in office 1997-2010) did nothing to reverse the marketization of the system. On the contrary, throughout the 1990s and 2000s new categories of schools were created in order to introduce more diversity in the system: 'specialist schools' (which would select up to $10 \%$ of pupils on the basis of ability), new 'faith schools' in addition to the older Anglican and Catholic based voluntary schools (selective on the basis of faith), Academies (originally intended to be partially funded by industry, and aimed at disadvantaged areas and pupils); adding to the already diverse system that included grammar schools which were never abolished. By the end of the 1990s, the number of locally controlled comprehensive schools was only $40 \%$ of the total of secondary schools across the UK. As Jones (2003) described, "pre-existing patterns of diversity had been accentuated to create a complex and subtly differentiated hierarchy of schools, whose status, reputation, and achievement levels varied considerably" (p.115).

In this changing education space, 'equality of opportunity' was recast by the New Labour government as 'inclusion' and it was to be operationalized through raising academic standards and the combating of the worse features of disaffection. Numerous policies and initiatives of the period focused on: the setting of targets of performance for teachers, schools and local authorities, frequent inspections with linking of financial resources to school improvement, high government intervention at the level of classroom practice and pedagogy. At the same time, the consecutive New Labour governments saw business as their main partner in education reform and appropriated business management models and discourses in the management of the education and wider public sector. But, the emphasis of the period in combating social exclusion also meant significant resources were directed towards the more marginalized parts of the population (Paterson, 2003). In education the official discourses established a causal relationship between social exclusion/inclusion and education success, and posited the latter as a form of differential consumption of educational opportunities. In this way, they marginalized the effects of governance structures on the production and distribution of educational and labour market opportunities (Alexiadou, 2011), captured in the New Labour education focus on 'standards not structures'viii.

\section{The Contemporary Context}

The education policy context of the last fifteen years is one of intensification of marketization reforms in both countries, although with the potential for interruptions in the privatization project due to a new Socialist-Green coalition government in Sweden since 2014. Initially the free school sector largely consisted of single schools run by for example parental and staff cooperatives, faith and other interest organizations - by and large non-profit. But, this has been 
changing fast: By 2013 a total of $13 \%$ of Swedish pupils at compulsory school attended a free school, and that figure was $26 \%$ for pupils in upper secondary (post-compulsory) level with large variations between the urban conurbations and the sparsely populated municipalities (SNAE, 2012). In addition, the free school market has rapidly changed since its emergence in the 1990s, when most free schools were small, single entities. In the early 2010s, the private school market is dominated by "Edu-business", large groups of companies that offer schooling in a 'chain' model - some of which have gone bankrupt in the recent years (Erixon Arreman \& Holm, 2011).

This high level of school privatization in Sweden was accompanied by a management of performance within schools, especially through activities of the Swedish National Agency for Education (SNAE) and the new School Inspectorate that has more extensive policy powers and possibilities for imposing sanctions than their predecessor (Rönnberg, 2012). In addition, during the 2000s grading and national testing increased considerably from an initially modest level. The National Agency is using since 2001 an information system (SIRIS), of quantitative information on national test results and grades, and qualitative information consisting mainly of Inspectorate reports. Most data is quantitative and based on grades and test results, for example in SIRIS, and in a website especially designed for school choice information for parents and students (Svenskt Näringsliv, Sveriges Kommuner och Landsting \& Friskolornas riksförbund 2015). In some systems user-/customer satisfaction questionnaires are also used. Research suggests that such indicators steer the teachers' and students' focus (Dahler-Larsen 2014), which imply that broad goals of schooling, such as citizenship, social inclusion and justice, are devalued in practice.

The SNAE also provides a statistical tool, SALSA, for analyzing relationships between grade statistics from year 9 and pupils' social background factors, such as share of students of nonSwedish ethnicity, gender and parents' education level. Importantly, in Sweden differentiating students by ability (through setting, streaming, or setting up of elite classes) is not allowed by law. The 2010 Education Act explicitly specifies that teaching for pupils in need of extra support should be given within the pupil's ordinary group (SFS, 2010). In terms of general principles of equality and inclusion it is important to state that the 2010 Education Act in Sweden, like its predecessors in the 1970s and 1980s, emphasizes the design of an education that fosters human rights, democratic values, and solidarity, and, recognizes that all people have equal value. Education should be 'equivalent' regardless of location, but "adapted to every child's individual needs" with schools having the legal responsibility to provide special support for children who require it to attain appropriate educational goals" (Education Act, 2010:800; Lundahl, et al, 2013).

In September 2014 the non-socialist coalition government was replaced by a minority government of the Social Democrats and the Green party. Prior to the change of government, market-like conditions for education, and undesired effects of these were recognized over party lines in the parliamentary state report of the Free-school Committee (SOU 2013:56). There seems to be a political commitment to more proactive policies towards reducing the differences between advantaged and disadvantaged schools and pupils. There is however no discussion about a reversal of the privatization, neither is there any serious challenge to the established practices and structures of parental choice and school competition. 
In England, there have been two governments in place since 2010, a Conservative-Liberal coalition government (2010-2015), and a new Conservative government elected in 2015 with no discernible difference in the broad commitments to education policy between the two as yet. What is distinct in this period is the persistence with which the post-2010 governments are pursuing the transfer of control from local authorities to individual school units, and the intensification of the policies of school autonomy through the Academies Programme: "even though various types of schools fail to deliver, the idea of independence has remained remarkably uncontaminated, but is reinvented through a process of forgetting" (Gunter \& McGinity, 2014:310). This government extended the scope and nature of Academies, that is now a status for any state-maintained school that wishes (or is forced) to convert to. The desirability of this type of school is high for this government, since, through the 2010 Academies Act, it allows a direct contractual relationship between the school and the Secretary of State for Education, but also entails significant freedoms for the schools. They can set their admissions policies, they do not have to adhere to the national curriculum, nor the regulations of teachers' pay (West, 2014). In that respect, the Academy status is providing more freedoms to schools in England than the free-school status does in Sweden - with the significant exception that no state school in England is allowed to make profit (something that the current UK government is keen to change, with reference to the Swedish reforms, see Rönnberg, 2015).

At the same time that competition increases with the higher than ever diversity of schools available to parents and pupils, the government has introduced a new curriculum reform that has distinct conservative features and a focus on traditional subjects, and a revision of assessment patterns (Smith, 2013). The reform was received with alarm for its equality implications by the National Union of Teachers: "inclusive practice appears to have been removed from the values underpinning the national curriculum" (NUT, 2012). The government have refuted these claims. Following the Equality Act of 2010, they have published a set of Equality Objectives for education policy (DfE, 2014), where they outline a vision of "a highly-educated society in which opportunity is more equal for children and young people no matter what their background or family circumstances" (p.2). These objectives are operationalised through four areas of action: (a) reinforcing the knowledge children gain through the National Curriculum and academic as well as vocational qualifications; (b) narrowing the achievement of disadvantaged children through monitoring, but also through 'encouraging Academy grammar (selective) schools to use pupil premium priority in their admissions'; (c) supporting families and vulnerable children; and, (d) providing parents with more choice between schools, giving schools more freedom, and raising teaching standards. These equality objectives are set against a policy context where the government's flagship schools (Academies, Free schools) are not obliged to follow the national curriculum, they are free to set their own admissions, and of course in a highly competitive marketized system, they have all the incentives to not heed the 'encouragement' of the government to recruit disadvantaged pupils.

In the next part of the paper, we shall briefly look at some of the outcomes of these reforms in the two countries, selectively drawing on our empirical research, in order to illustrate the effects of marketization on issues of inclusion and equality. 


\section{Part II}

\section{The context of the market - responses \& outcomes}

The school market in England has been developing since 1988, and against an already diversified schooling landscape. In Sweden the situation has been different, with a shorter time span of developments, but a transformation into a situation more reminiscent of a proper market than anywhere else in Europe. Sweden is probably the only country in the world where schools can be run by limited liability companies, which without special restrictions can distribute the surplus to shareholders (Vlachos, 2011).

In England, the large diversity of secondary school 'types' create a very rich market place, forming throughout the 1990s and 2000s. The position of a school in the local school market has direct implications for parental and student choice, but also for selection of pupils by schools. In the English Local Authorities of our research we encounter a large range of school types, Comprehensive, Grammar schools, Trust and Faith schools, Academies, and a City Technology College. Grammar schools can use a process called 'fair banding' (where they select applicants in proportion to their numbers in bands across the ability range) and this of course has an impact on the intake of pupils admitted to the non-selective Comprehensive schools. In Sweden, there is less diversity in terms of distinct school types. There has been an ambition of the reform that the introduction of free schools would lead to more innovative and diverse pedagogic practices, but similar to other countries this has not really materialised (SNAE, 2004, Lubienski, 2009). Schools in Sweden are reported to engage in extensive activities of 'profiling' and 'marketing' their provision "as unique 'brands"' and in relation to particular pedagogical identities (Holm, 2013). In our study we have found that this sort of branding refers less to type of provision, and more to a particular 'ethos' that corresponds to either traditional, elitist and academic-aspiring themes, or one oriented towards personal and social development, aimed mainly at schools with more vocational orientation (Dovemark \& Holm, 2015; Lundström \& Holm, 2011; 2016). Only one school of our study had an explicit intention to 'foster collectivity', and to 'promote an ethos of social justice, tolerance and inclusivity' (ibid.). In that respect 'diversity' is a dimension that makes the two market systems of England and Sweden very different in their operation.

There are two sets of themes that we wish to highlight here from our empirical work. The first refers to the nature of competition as it is shaping in the local markets of our two countrystudies and how this links to issues of between-school collaboration and (self)selection of pupils. The second theme extends this discussion to the connected issues of diversity and segregation.

\section{Competition, collaboration and school selectivity}

\section{Sweden}


Competition between schools in Sweden intensified in the 2000s, when a significantly larger number of private free schools were established. The increased competition for students has led to a targeting of specific categories of students, and the investment of resources to market and 'brand' schools to parents and students. Similar to our findings from research in our English local authorities, the Swedish municipalities of our study respond to this new environment depending on the nature of the local market. So, here we observe a move of students from rural municipalities to larger towns, in line with national trends (SNAE, 2012), which results in certain schools and municipalities loosing significant numbers of students, and hence resources:

Young people are attracted to the cities. For them it is OK to commute to town, but very few from the town commute to the provincial areas.... The surrounding municipalities have been hit really hard. (Headteacher, River Town)

The admission rules to schools may also vary in Sweden. The River Town's policy of letting as many students as possible obtain their first school choice has resulted in overcrowded schools in the town, and, in times of decreasing student numbers, has thus reduced school choice in the surrounding municipalities. The Liberal Chair of the Education Board in the Municipality seems to assume that school choice implies inclusion and quality, largely overlooking the fact that competition between the region's municipalities impoverishes some municipalities' schools:

It might irritate some other municipalities that have difficulties retaining their students, but the school shouldn't exist for the municipality's sake ... it is the student who must choose and the student has the right to choose to study in River Town if he/she believes better education is offered here. The student has the right to choose an independent school if he/she thinks it offers a better education. The learner is constantly in focus, .... (Chair, River Town)

In Forest Town (a Municipality with a Social Democratic local government), the priorities are different. The distribution of students is similarly based on students' choice, however, the process of admission to different schools is limited by fixed number of places at each school (both municipal and free schools). While marketing high numbers of successfully completed studies within the stipulated 3 years of time is a positive feature for a municipal school (both for marketing purposes, and in good economic performance in the municipality), different practices tend to take place in free schools. Free schools tend to have a larger proportion of students that take a fourth year to complete their studies (SKL, 2015:24) - this brings additional voucher money:

When we market this (municipal) school we emphasize that $88 \%$ of our students pass the upper secondary programs in 3 years, so compared to $72 \%$ throughput of students in the Rose school (a free school), we are told that we have good results ... However, there is an economic incentive for Rose school to receive voucher funding for a $4^{\text {th }}$ year, while for us a $4^{\text {th }}$ year means a cost - how logical is that? (Teacher, Field School, Forest Town).

In Bay City, the pattern of periphery-centre movement has resulted in the recent closure of a large municipal school situated in the outskirts of the city with negative implications for the 
less mobile students who were left 'behind'. This movement is highly correlated with the students socio-economic and ethnicity background.

Many of the students in our study tend to identify with schools that seem to carry a similar 'capital' as themselves, when they consider their post-compulsory school options and report a willingness to take a similar academic or vocational direction of post-compulsory study as their parents (Erixon Arreman, 2014):

I have learnt how to weld from my dad, as I used to work with him in the summer holidays. ... I want to have this particular programme. (Boy, Hill School, Lake Village)

My dad has always told me since I was six years old - when you grow up you shall be a plumber! He has repeated that it's a good programme. (Boy, Meadow School, Forest Town)

The combination of the high degrees of competitiveness of some municipalities (and schools within), the indirect selection of schools through branding and profiling marketing strategies, leads a limitation of choices for students who tend to apply to schools where they 'feel most comfortable'.

\section{England}

After 25 years of competitive processes in England, local markets outside the big cities seem to be to some degree 'settled'. More than half of the state-funded secondary schools in England are now Academies, and 32,5\% of school pupils are enrolled in Academies and Free schools - some of which are Academies (DfE, 2015). Schools have their positions in the hierarchy of the local market place, and that position is reflected in the degree of (explicit) selectivity the schools exercise in their admissions of pupils, as well as their exam results and perceived status in the locality (there are 163 entirely selective state-funded secondary schools, and they educate $5 \%$ of the total school population, (ibid.), but there are many more partially-selective schools). In our study, we observe a degree of collaboration between schools of 'similar' status and position. The schools in our two Local Authorities describe a situation of moderate competition over the past decade, as a result of old 'understandings' and agreements. Our data suggests that this 'settling' is contingent on (a) the needs to share resources during times of cost reductions, and (b) an understanding developed between headteachers and the local authority based on older versions of 'catchment areas' for students. But, it is also fragile, dependent on the stability of local demographics, and seems to be regulated by rules of engagement about 'who participates'. The participation in these collaborative ventures in our research tends to come primarily from the head-teachers of the comprehensive schools in both authorities:

"We respect each other's turf so to speak ... We have the Secondary Heads group, and a Learning Partnership - all the secondary head-teachers and also Further Education, and the local authority sends a representative...They are all invited, one of the Academies doesn't attend frequently, the other from time to time ... but the Thomas Gunn Head (a City Technology College) doesn't engage with the secondary heads group at all" (Headteacher, Edgerton Technology College) 
"The head-teachers have agreed that we don't try and market within each other's catchment areas although the gloves are coming off a little ... There's been a demographic dip in the Town ... and there have been some slightly underhand things going on recently, like prospectuses turning up in schools the way they shouldn't be. The Heads are going to sit down with each other and decide whether it's a free-for-all or whether the old catchment area approach will still apply" (Deputy Headteacher, Blake High School)

This clustering of schools to work with other 'similar' schools has led to a local market situation whereby collaboration is taking place between the local Comprehensive schools (despite their slightly different governing status, they are all non-selective). These schools have a mixed socio-economic intake of pupils, but a larger proportion of the 'bottom end' of performance of the pupil's population which also includes high number of children with English as a second language. During our interviews, the pupils in these schools seem to be very clear about the position of their school in the hierarchy of the local market, and for a large number of them, their current school was their second or third choice:

I applied to Thomas Gunn first but I didn't get in. You have to have a test, but they also want to meet you and talk to you ... they look at your achievements, at sports and such things, but they also look at your personality. After that, this school was my first choice (Girl, Edgerton Technology College)

I also applied to Thomas Gunn, but I had a disadvantage because I am dyslexic - I didn't get in. They have to take up to a quota of disabled pupils, but they don't take more. Apart from that EC was my first choice. And, here they have told me from the start that my dyslexia would not be a problem - and it's been fine so far. (Boy, Edgerton Technology College)

The 'top' selective schools in the area of our study (the Grammar school, the City Technology College, and one of the Academies) are operating pretty independently, and without forging particular links with other secondary schools.

In both England and Sweden our empirical data point to similar patterns of a competitive system whereby schools' competitive behaviour depends to a large extent on the degree of autonomy and independence different schools exhibit. The Swedish study points to a fairly fluid and mobile school market that includes school closures. The collaboration-withincompetition English market model of our two local authorities seems to be more settled and less acute, but is highly dependent on fluctuations of the student population in the area, and stratified by perceived status of the different schools, in turn linked to their socio-economic intake of students.

\section{Diversity \& segregation}

The second theme we wish to highlight from our data, refers to the connections between diversity of school types in the localities of our fieldwork, and school segregation patterns. Reports of social differentiation of schools comes from many qualitative studies in the field of education over the last 20 years, that describe higher stratification in terms of achievement between different socio-economic and ethnic groups as a result of school marketization although it is harder to find quantitative research to support this causality. As Bunar (2010) 
has argued, different research methodologies have produced contradictory or ambiguous results with regard to the outcomes of the marketization policies, and hence, there are "no clear answers and guidelines whether the policy is delivering its promises or on the contrary worsening the state of equity in education" (p.1).

Both Sweden and England are countries with high levels of housing segregation, particularly in the big urban centres although this is more intense in England due to the higher degree of income inequality in the $\mathrm{UK}^{\mathrm{ix}}$. This has been the primary source for school segregation that has a socio-economic and-depending on the location, a strong ethnicity dimension, both of which are in turn reflected in the school population, although with significant variations depending on the ethnic minority (Lindbom, 2010; Burgess \& Wilson, 2005). The question of the impact of marketization policies on this segregated pattern has been researched extensively (for discussion see, Bunar, 2010 for Sweden, and Law \& Swann, 2011 for England). There seems to be consensus from the large scale quantitative studies that the effect of school choice reforms on the segregation patterns of schools is not as great as either the proponents or the sceptics of the policy reforms had predicted (positive or negative respectively, see Gorard, 2014; Jenkins et al., 2008; Lindbom, 2010). Still, as a result of a combination of decentralisation and parental/student choice of schools, segregation seems to exacerbate the effect of 'creaming' of the best students from the schools with the higher reputation. Researchers have recently demonstrated that parental school choice further increases the differences between schools in terms of social composition, as well as analysed the underlying mechanisms of this phenomenon (Trumberg 2011. See also Böhlmark \& Holmlund 2010). Privileged groups tend to use the school choice possibilities to avoid mixing with less privileged ones, or with ones from a different ethnic background (Östh, et.al, 2013). As our empirical evidence suggests, the existing social differentiation of neighbourhoods is not merely reflected in the composition of schools (a feature that predates marketization reforms), but it intensifies certain aspects of segregation through the actions of both school actors, but also self-sorting of students in a desire to be in schools with peers similar to themselves (Erixon Arreman, 2014; Holm, 2013).

\section{Sweden}

The majority of OECD and PISA studies place Sweden in a significantly better position than the UK in relation to both social differentiation and school segregation (Jenkins et al., 2008; OECD, 2015), but there is still considerable segregation in terms of housing areas which is reflected in the social composition of schools. In addition, when children of immigrant origin who live in deprived urban areas move to more middle-class schools, researchers find that the ethnic Swedish children tend to move to a different school (Bunar, 2010; Östh et al, 2013).

We see a similar (in the reverse) pattern in one of our municipalities (Bay City) in which one of the schools is losing students to neighboring schools. One of their suburban schools, Ash Public (with a large number of students from ethnic minority backgrounds), is struggling with low exam results and a poor reputation. Many of the high achieving students in the neighbourhood leave and apply to more popular schools (municipal and independent) in the 
city center. However, a large number of these students tend to come back to Ash Public after a while, so called "returners", as they felt alienated and excluded as immigrants at the city schools. To avoid closure, the municipality has decided to change the Ash Public profile and promote a more academic orientation and recruit students mainly from the local neighbourhood. The previous vision of attracting applicants from other districts has now been abandoned. The strategy is to offer young people educational opportunities in their own neighbourhood and to make sure they can complete upper secondary education. The municipality has tried various reorganizations to make all municipal schools attractive, but this has been a problematic process. For example, moving a high-status programme to a school with a poor reputation resulted in students choosing that programme at an independent (free) school instead.

A highly marketized system, however, assumes that there is diversity of provision to allow parents and students to make choices. One of the original arguments of the proponents of marketization in Sweden was that the reform will allow pedagogical innovations, which will raise the overall quality of schooling. But, reports from both official sources and researchers suggest that the opposite is happening. Schools are becoming less diverse in terms of pedagogy and more uniform in the provision they offer to students. Instead, the diversification we observe seems to relate more to student composition, with students and parents selecting schools that have a similar profile to themselves, which is in effect a reflection of socio-economic and ethnicity profiling (Dovemark \& Holm, 2015; Lindgren, 2010), or socio-economic and gender profiles in the vocational upper secondary school level (Hjélmer, Lappalainen, \& Rosvall, 2014). This profiling tends to be also connected to academic achievement as well as aspirations for certain types of post-compulsory career paths:

And initially I thought, and still think, that the idea about free schools is right, when you give different students with different learning styles the opportunity to apply to various schools which suit them best, and the idea is right. (Headteacher, Park Public, River Town)

I think it is easier for students at vocational schools ... the tolerance is bigger from other students as well as pedagogues... (Headteacher, River Town)

These selected examples illustrate the tensions between marketization and inclusion, and the difficulties in participating successfully in a competitive school market particularly in socially disadvantaged contexts.

\section{England}

Comparative research of OECD countries in the 2000s has found that England is amongst the high segregation countries - that, some researchers attribute to the prevalence of parental choice (Jenkins et al., 2008). This degree of segregation in England is "accounted for by the uneven spread of children from different social backgrounds within the state sector" (Ibid 2008:35). But, similar comparative studies drawing on PISA results argues that socioeconomic segregation (or clustering of similar students) between schools in the UK has declined, not increased, as a result of weakening the link between housing and schools for all 
families (Gorard \& Smith, 2004). What this literature identifies as more readily contributing to high levels of segregation is related to poverty and residential segregation, compounded by ability and faith-based selection of students by schools, as well as travel limitations (which in turn are connected to socio-economic background). Following this evidence, the more threatening to equity and inclusion market-based policy in education is that of increasing diversity of schools, which, coupled with parental choice and existing residential patterns based on socio-economic and ethnic lines, presents a higher risk for an increase in segregation (Gorard, 2014).

In the UK and England in particular, part of the debate around socio-economic based segregation and its links to schools has been concerned with the issue of student selection. Different types of schools have very different shares of disadvantaged pupils. For instance, Gorard (2014) argued that: "around one third of FSM pupils in England would have to exchange schools in order for all schools to have their fair share. For as long as records exist, and for both primary and secondary sectors, segregation by poverty has occurred at between 30 and 40\%" (p.273). In this context, new Faith or Academy schools seem to appear in areas that already have inequitable school mixes and as such, they do not contribute to any desegregation pattern (ibid.).

In our study, this is confirmed. The fairly quiet and mature English local market where each school 'has found their place' (Geography Teacher, Blake High School), is characterised by a high degree of segmentation and concentration of different 'types' of children to the different types of schools, a pattern that predates the marketization reforms of the late 1980s, but has intensified since. The operation of schools that are selective on the basis of ability of pupils, specialisation, or faith, as well as the different degrees of freedom certain school types have over their admissions policies and funding, results in a fairly segregated picture, with the schools in our research ending up with larger representations of children from 'difficult' backgrounds:

"Thomas Gunn is a selective school but they apply what is called fair banding. They take $50 \%$ of the kids from all top sets of all the secondary schools in the Town. So, they take a band of kids from the top of the bottom, the top of the middle and the top of the top. So, it means that what is left is the less able of those bands - they cream them off through their entrance exam... Last year they took 15 kids that would have come to us, that's the biggest hit we've had, virtually half of would-be top set kids have gone there" (Deputy Headteacher, Edgerton Technology College)

"What we end up with is a high proportion of Free School Meal ${ }^{\mathrm{x}}$ kids, and a high proportion of kids where English is an additional language ... overall it means we have got more challenging kids. (Deputy Headteacher, Blake High School)"

We've got 3 feeder primary schools, two of those schools have created their own cooperative trust, we're partners in that and we're looking to become full members. Of those schools, we have one in 'special measures', we have one 'satisfactory' and one that 'requires improvement ${ }^{\text {'xi }}$ so we take kids from all over the Town but a vast majority of the kids we take come from those 3 schools. And they were all in significant difficulty. (Headteacher, Edgerton Technology College) 
As the teachers and headteachers in these schools have told us during our interviews, the area was always operating a semi-selective system (with one selective Grammar school, two partly selective Faith schools, and a partly selective City Technology College), but now the additional diversity of schools has meant that the non-selective Comprehensives having to take a larger proportion of the weak and very weak local students, and a lower proportion of the stronger ones.

\section{Concluding Remarks}

Public education and the institution of the school have been transformed over the last few decades in both Sweden and England in ways that seem, at the surface, similar. The adoption in both countries of institutional designs that draw on the principles of the market and managerialism, combined with the opening up of the school systems to private interests and actors have challenged or changed the values of solidarity and equality that underpinned many of the older narratives of education purpose. In tracing the trajectories of educational change in the two countries, and exploring the contemporary experiences of reforms by school actors, we have argued that despite the common dominant discourses of education reform, the two systems have responded rather differently.

England, characterised by a significantly more diverse and fragmented system of schooling, has been an enthusiastic proponent of marketization that, as Jones et al. (2008) argue has been introduced early, with great speed, and with a "deeper level of embeddedness" that institutionalised effectively the routines of a neo-liberal education (p.196). In such a context, introducing further diversity, differentiation, and competition in the system, followed in largely uncontested subsequent reforms. As a consequence the schooling system is highly segregated, and, socio-economic background, ethnicity and religion define to a large extent the opportunities for success. Inclusion in this context is part of a policy mantra that - despite the rhetoric to the opposite, is satisfied with providing 'equal opportunities' to compete, with recognition that unequal contenders have little chance of equal outcomes.

Sweden is an example of surprising contrasts. The extent and depth of privatization of the system is unparalleled in Europe, and the proponents of such reforms have held the policyshaping and making initiative with little signs of a reversal. The long admired Swedish welfare state that emphasised the building of citizenship and the creation of a democratic society, has transformed towards individualised notions of responsibility, freedom of choice and local variation. Schooling reforms since the 1990s intensified curricular and institutional differentiation, and legitimised the principle of diversity in a marketised system. The traditional emphasis on collective participation and the achievement of equality in and through schooling, have weakened through decentralisation processes and individualisation, in what Lindgren (2010) views as an alternative 'narrative' of Sweden. But, Sweden has retained strong elements of the social democratic ethos that are still visible in the functions, values and governance of education.

In our policy analysis and empirical work we find what Harvey calls the "uneven geographical development of neoliberalism" that entails "multiple determinations and not a 
little chaos and confusion" (2005:13), even within the same country. The tensions between the 'monopoly' and 'specialisation' paradigms of social inclusion are fought over educational change in both countries, and the different historical roots of the two schooling systems are mediating the neo-liberal pressures in distinct ways.

\section{Acknowledgements}

We wish to thank the teachers, head-teachers, local government officials and politicians and students in Sweden and England for giving us their valuable time, access to documents and course materials, and allowing us to attend teaching sessions.

\section{Funding}

The author(s) disclosed receipt of the following financial support for the research, authorship, and/or publication of this article: This work was supported by the Swedish Research Council for the research (research project, 2012-2015 (5509)).

\section{NOTES}

${ }^{\mathrm{i}}$ In 1999 the United Kingdom (UK) devolved powers to a Parliament in Scotland, and Assemblies in Wales and Northern Ireland, with 'education' being one of the devolved policy areas. References to 'the government' in this paper point to the UK government but the location of our empirical work is within England. Education policies are different between the countries of the UK, and so are institutional histories and value systems that make Scotland and Northern Ireland quite distinct as compared to England and Wales.

ii 'Inclusive and competitive? Changing understandings and practices of social inclusion in upper secondary school', funded by the Swedish Research Council 2012-2015 (Ref. no. 2011-5509).

iii In England this refers to the ages of 11-18 (11-16 compulsory school, 16-18 post-compulsory), in Sweden 13-18 (that include years 7-9 and then the post-compulsory upper secondary education)

iv There are three terms in use in this article that refer to the 'local level' of administration and governance of schools: the term 'municipality' for the Swedish local government level responsible for schooling; the term 'local authority' in England, and also, for reasons of convenience, we sometimes use the more generic term 'local government' when we wish to refer to this level of school authority in both countries.

${ }^{v}$ In England, we carried out research in two secondary schools in the Midlands (for anonymity purposes called Blake High School - with 985 pupils, and Edgerton Technology College - with 684 pupils). Both schools have been rated as 'Satisfactory' by Ofsted in 2012. Blake High School (a Community school) has above average numbers of pupils who have a statement of special educational needs. Edgerton Technology College (a Foundation school) caters for an area of relatively high deprivation, and it has high proportion of pupils for whom English is an additional language. It also has above the average proportion of pupils who are disabled and supported for special educational needs. 
In Sweden we researched four municipalities, here called Bay City, Lake Village, Forest Town and River Town. In-depth interviews were collected at eight schools; five municipal schools and three free-schools. The schools varied in size, scope and outcomes; in the generally larger municipal schools student numbers generally exceeded 1000 students and included up to 2000 students. The generally smaller free-schools had around 300 and 350 students (Beech Free, Oak Free). Out of these schools some serve areas of deprivation and/or have a large number of ethnic minority students (for instance, Ash Public), and some are very successful in both recruitment and performance terms (Field school), with the rest being more average.

${ }^{\text {vi }}$ By 1988 comprehensive schools constituted $87 \%$ of all secondary schools across the UK, but their numbers varied across different parts of the UK (in Scotland they comprised 99\%, whereas in N. Ireland they were a much smaller proportion. From: HMSO (1989) Educational Statistics for the UK. London).

${ }^{\text {vii }}$ In 2015, the independent (private, fee-paying) school sector in the UK as a whole educates around 625,000 children, that accounts for around 6,5\% of the total number of children in the UK (and 7\% of the school children in England). The figure is more than 18\% of pupils over the age of 16.

(Independent Schools Council, www.isc.co.uk)

viii The phrases 'standards not structures' featured in the first White Paper that the new Labour government published on education (DfEE 1997, Excellence in Schools, p.5). It signalled the departure of the government from the old left concerns with egalitarian education policies (and debates about comprehensive schooling), a move towards a more 'pragmatic' and modern set of policies that draw on research evidence on 'what works'.

${ }^{\text {ix }}$ According to the latest OECD reports on Income Inequality, Sweden still belongs to the group of most equal countries. But, as a result of changes in the redistributive tax system and benefits it has seen "a surge of income inequality since the early 1990s", with the growth in inequality in the period 1985-2010s being "the largest among all OECD countries". In 2012 the average income of the top $10 \%$ of earners was 6,3 times higher than that of the bottom $10 \%$. (OECD, 2015)

In the UK, the level of income inequality has been "well above the OECD average in the last three decades". Changes in taxes and benefits of the last 10 years have reduced the average income level of the poorest $10 \%$ of the population by $2 \%$ in real terms. In 2012 the average income of the top $10 \%$ of earners was almost 10 times as large as for the poorest 10\%. (OECD, 2015b).

${ }^{x}$ Free School Meals - "In England a Free School Meal (FSM) is a statutory benefit available to school-aged children from families who receive other qualifying benefits and who have been through the relevant registration process" (Department for Work and Pensions, 2013. Free school meal entitlement and child poverty in England). It is used in research as a proxy indicator for poverty.

In Sweden free school meals are offered to all pupils in compulsory and upper secondary education regardless of their families' socioeconomic situation.

${ }^{\mathrm{xi}}$ These are ratings by the school inspectorate OFSTED. 


\section{References}

Alexiadou, N. (2001) Researching policy implementation: interview data analysis in institutional contexts. International Journal of Social Research Methodology, Theory and Practice, 4(1), 51-61.

Alexiadou, N. (2011) Social inclusion and leadership in education. Education Inquiry, 2(4), 581-600.

Alexiadou, N. (2016) "Equality and education policy in social Europe - An example from the case of Roma". Under review.

Ball, S.P., Maguire, M. and Braun, A. (2012) How Schools do Policy. Policy enactments in secondary schools. London \& New York. Routledge.

Beach, D. \& Dovemark, M. (2011) Twelve years of upper-secondary education in Sweden: The beginnings of a neo-liberal policy hegemony. Educational Review, 63(3), 313-327.

Benn, C., Chitty, C. (1997) Thirty Years on: Is Comprehensive Education Alive and Well, or Struggling to Survive? London: David Fulton.

Böhlmark, A. \& Holmlund, H. (2010) 20 år med förändringar $i$ skolan. Vad har hänt med likvärdigheten? [20 years of changes in schools. What has happened to equality?] Stockholm: SNS.

Blomqvist, P. (2004) The choice revolution: Privatization of Swedish welfare services in the 1990s. Social Policy and Administration, 38:2, 139-155.

Brock, C., Alexiadou, N. (2007) The United Kindgom. In: W.D. Horner, H.B. von Kopp, and W. Mitter (eds) The School Systems of Europe. Pp.826-851. Dordrecht, Klewer-Springer.

Bunar, N. (2010) Choosing for quality or inequality: Current perspectives on the implementation of school choice policy in Sweden. Journal of Education Policy, 25(1), 1-18.

Burgess, S. \& Wilson, D (2005) Ethnic segregation in England's schools. Transactions of the Institute of British Geographers, 30(1), 20-36.

Crouch, C. (1999) Social Change in Western Europe. Oxford: Open University Press.

Dahler-Larsen, P. (2014) Constitutive effects of performance indicators: Getting beyond unintended consequences. Public Management Review, 16(7), 969-986.

Dale, R., and Robertson, S.L. (2009) Beyond methodological 'isms' in comparative education in an era of globalisation. In R. Cowen \& A. M. Kazamias (eds) International Handbook of Comparative Education. Pp. 1113-1127. Springer Science and Business Media B.V.

David, M. (2003) Parents, Gender and Education Reform. Cambridge: Blackwell Publishers. Department for Education (DfE) (2014) Equality Objectives. September 2014. 
Department for Education (DfE) (2015) Schools, pupils and their characteristics. January 2015. Statistical First Release. National Statistics, SFR 16/2015.

Dovemark, M. \& Holm, A-S. (2015) Pedagogic identities for sale! Segregation and homogenization in Swedish upper secondary school. British Journal of Sociology of Education, EPublication. DOI: 10.1080/01425692.2015.1093405.

Erixon Arreman, I. (2014). Student perceptions of new differentiation policies in Swedish post-16 education. European Educational Research Journal, 13(6), 616-631.

Erixon Arreman, I. \& Holm, A-S. (2011) Privatisation of public education? The emergence of independent upper secondary schools in Sweden. Journal of Education Policy, 26(2), 225243.

Esping-Andersen, G. (1993) The Three Worlds of Welfare Capitalism. Princeton: Princeton University Press.

Gulson, K., Clarke M., Bendix Petersen, E. (2015) "Introduction: theory, policy, methodology”. In K. Gulson, Clarke, M., Bendix Petersen, E. (eds) Education Policy and Contemporary Theory: Implications for Research. Pp.1-13. London: Routledge Taylor \& Francis Group.

Harvey, D. (2005) A Brief History of Neoliberalism. Oxford: Oxford University Press.

Holm, A-S. (2013) A sea of options. Students' perspectives of market competition in upper secondary school. Nordic Studies in Education, 33, 284-299.

Gorard, S. (2014) The link between Academies in England, pupil outcomes and local patterns of socio-economic segregation between schools. Research Papers in Education, 29(3), 268284.

Gorard, S. \& Smith, E. (2004) An international comparison of equity in education systems. Comparative Education, 40(1), 15-28.

Gunter, H. McGinity, R. (2014) The politics of the Acadmies programme: natality and pluralism in education policy-making. Research Papers in Education, 29(3), 300-314.

Hjélmer, C., Lappalainen, S., \& Rosvall, P-Å. (2014) Young people and spatial divisions in upper secondary education. In A.-L. Arnesen, E. Lahelma, L. Lundahl, \& E. Öhrn (eds.), Fair and competitive? Critical perspectives on contemporary Nordic Schooling (pp. 85-102).

London: The Tufnell Press.

Jenkins, S.P., Micklewright, J., Schnepf, S.V. (2008) Social segregation in secondary schools: how does England compare with other countries?. Oxford Review of Education, 34(1), 21-37.

Jones, K. (2003) Education in Britain: 1944 to the Present. London: Polity Press. 
Jones, K., Cunchillos, C., Hatcher, R., Hirtt, N., Innes, R., Johsua, S., Klausenitzer, J. (2008) Schooling in Western Europe. The New Order and its Adversaries. Houndmills: Palgrave Macmillan.

Junemann, C. Ball, S. (2013) ARK and the revolution of state education in England. Education Inquiry, 4(3), 423-441.

Lappalainen, S., Lahelma, E. (2015) Subtle discourses on equality in the Finnish curricula of upper secondary education: reflections of the imagined society. Journal of Curriculum Studies, Epublication.

Law, I., Swann, S. (2011) Ethnicity and Education in England and Europe: Gangstas, Geeks and Gorjas. Farnham: Ashgate Publishing.

Lindbom, L (2010) School choice in Sweden: Effects on student performance, school costs, and segregation. Scandinavian Journal of Educational Research, 54:6, 615-630.

Lindgren, J. (2010) Spaces of social inclusion and exclusion. A spatial approach to education restricting and identity in Sweden. Education Inquiry, 1(2), 69-89.

Lubienski, C. (2009) Do quasi-markets foster innovation in education?: A comparative perspective. Education Working Papers, No. 25, OECD Publishing.

Lundahl, L. (2002) Sweden: decentralization, deregulation, quasi-markets - and then what?. Journal of Education Policy, 17:6, 687-697.

Lundahl, L. (2014) Suède: Les marches de l' éducation, l' autonomie locale et le contrôle gouvernemental (Sweden: School markets, local autonomy and state control). In Jacques Fialaire (ed) Éducation, Formation, Recherche. Quelle place pour les collectivités territoriales? Droit et Gestion des Collectivités Territoriales. Pp.229-235. Paris: Le Moniteur des Travaux Publics.

Lundahl, L., Erixon Arreman, I., Holm, A., Lundström, U. (2013) Educational marketization the Swedish way. Education Inquiry, 4(3), 497-517.

Lundström, U. (2015) Systematic quality work in Swedish schools. Intentions and dilemmas. Scandinavian Journal of Public Administration, 19(1), 23-44.

Lundström, U. \& Holm, A-S. (2011) Market competition in upper secondary education: Perceived effects on teachers' work. Policy Futures in Education. 9(2), 193-205.

Lundström, U. \& Holm, A-S. (2016) Municipalities as school market actors: inclusion outcompeted. Forthcoming. Scandinavian Journal of Educational Research.

Montin, S (2006). Styrnings- och organisationsspåret - teoretiska perspektiv och empiriska illustrationer. Örebro: Samhällsvetenskapliga institutionen, Örebro Universitet.

NUT (2012) The Framework for the National Curriculum - A Report By The Expert Panel of The National Curriculum Review: the NUT's Response. National Union of Teachers.

OECD (2002) Education at a Glance. Paris: OECD. 
OECD (2012) Equity and Quality in Education, Supporting Disadvantaged Students and Schools. Paris: OECD.

OECD (2015) Income inequality data update: Sweden, January 2015. http://www.oecd.org/sweden/OECD-Income-Inequality-Sweden.pdf

OECD (2015b) Income inequality data update and policies impacting income distribution: United Kingdom, February 2015. http://www.oecd.org/unitedkingdom/OECD-Income-Inequality-UK.pdf

Paterson, L. (2003) The three educational ideologies of the British Labour Party, 1997-2001. Oxford Review of Education, 29(2), 165-186.

Phillips, D., Ochs, K. (2004) Researching policy borrowing: Some methodological challenges in comparative education. British Educational Research Journal, 30(6), 773-784.

Rawolle, S. (2013) Understanding equity as an asset to national interest: developing a social contract analysis of policy. Discourse: Studies in the Cultural Politics of Education, 34(2), 231-244.

Rönnberg, L. (2012) Reinstating national school inspections in Sweden: The return of the state. Nordic Studies in Education, 32(2), 69-83.

Rönnberg, L. (2015) Marketization on export: Representations of the Swedish free school model in English media. European Educational Research Journal, 14(6), 549-565.

Sejersted, F. (2011) The Age of Social Democracy. Norway and Sweden in the Twentieth Century. Woodstock: Princeton University Press.

SFS (2010:800) Education Act. Stockholm: Government Offices of Sweden.

Silver, H. (1994) Social exclusion and social solidarity: Three paradigms. International Labour Review, 133, 531-578.

SKL (2015) Öppna jämförelser: gymnasieskola 2015. Stockholm: Sveriges Kommuner och Landsting. http://skl.se/tjanster/merfranskl/oppnajamforelser/gymnasieskola.1022.html Published 2015-12-14. Retrieved: 2015-12-18.

Smith, H.J. (2013) A critique of the teaching standards in England (1984-2012): discourses of equality and maintaining the status quo. Journal of Education Policy, 28(4) 427-448.

SNAE (2004) Vad kostar de fristående skolorna? (How much do the free schools cost?). Swedish National Agency for Education: Stockholm.

SNAE (2012) Mapping the School Market. Synthesis of the Swedish National Agency for Education's School Market Projects. Swedish National Agency for Education. Stockholm.

Social Mobility and Child Poverty Commission (2014) Elitist Britain?

https://www.gov.uk/government/uploads/system/uploads/attachment_data/file/347915/Elitist_ Britain___Final.pdf (accessed, 14/12/2015).

SOU (2013:56) Friskolorna i samhället (Freeschools in society). Stockholm:

Utbildningsdepartementet. 
SOU (2014:5) Staten får inte abdikera - om kommunaliseringen av den svenska skolan (The state cannot abdicate - regarding municipalisation of the Swedish school). Betänkande av Utredningen om skolans kommunalisering. Stockholm: Utbildningsdepartementet.

Svenskt Näringsliv, Sveriges Kommuner och Landsting \& Friskolornas riksförbund (2015). Grundskolekvalitet [Compulsory school quality]. http://www.grundskolekvalitet.se/ Swedish Competition Authority (2009) Referat. Kammarrätten i Stockholm (Summary. The Court Kammarrätten Stockholm). Stockholm: Competition Authority.

Telhaug, A. O., Mediås, O. A., Aasen, P. (2004) From collectivism to individualism? Education as nation building in a Scandinavian perspective. Scandinavian Journal of Educational Research, 48:2, 141-158.

Vlachos, J. (2011) Friskolor i förändring. In L. Hartman (Ed.) Konkurrensens konsekvenser. Vad händer med svensk välfärd?. Pp.66-110. Stockholm: SNS förlag.

Walford, G. (2009) Private schools in England. Zeitschrift für Pädagogik 55(5), 716-731.

West, A. (2014) Academies in England and independent schools (fristående skolor) in Sweden: policy, privatisation, access and segregation. Research Papers in Education, 29(3), 330-350.

Östh, J, Andersson, E., Malmberg, B (2013) School choice and increasing performance difference: A counterfactual approach. Urban Studies, 50, 407-425.

\section{Author biographies}

Nafsika Alexiadou is Professor of Educational Work in the Department of Applied Educational Science, University of Umeå, Sweden. Her research interests are in education policies at national and at European Union levels, comparative research, and studies on inclusion. Email: Nafsika.alexiadou@umu.se

Marianne Dovemark is Associate Professor at the Department of Education and Special Education, University of Gothenburg, Sweden. Her research interests are in educational ethnography, focusing on structural factors such as class, gender and ethnicity, and devoted to issues of power and influence as these relate to school governance and market orientation. Email: marianne.dovemark@gu.se

Inger Erixon-Arreman is Associate Professor in the Department of Applied Educational Science, University of Umeå, Sweden. Her main research interests are in education policies, with focus on upper secondary education and teacher education. Email:

inger.erixon.arreman@umu.se

Ann-Sofie Holm is Associate Professor at Gothenburg University, Department of Education and Special Education. Her main research field is sociology of education with focus on gender constructions in school, but also on aspects of inclusion and marketisation of the Swedish education system. Email: ann-sofie.holm@gu.se 
Lisbeth Lundahl is Professor of Educational Work at the department of Applied Educational Science at Umeå University, Sweden. Her research interests concern education politics, youth politics and young people's school-to-work transitions. Email: $\underline{\text { lisbeth.lundahl@umu.se }}$

Ulf Lundström is Associate Professor in the Department of Applied Educational Science, University of Umeå, Sweden. His research interests lie within the areas of the teaching profession, education policy and evaluation. Email: ulf.p.lundstrom@umu.se 